\title{
THE DEVELOPMENT OF EUROPEAN INSURANCE MARKET INFRASTRUCTURE
}

\author{
Antonina Sholoiko \\ Department of Insurance, Banking and Risk-Management \\ Taras Shevchenko National University of Kyiv \\ 64/13 Volodymyrska str., Kyiv, Ukraine, 01601 \\ sholoiko@ukr.net
}

\begin{abstract}
The aim is to consider the development of different elements of European insurance market infrastructure. The next tasks of the study were done: to generalize main indicators of the development of European insurance market from 2012 to 2016; to characterize elements of European insurance market infrastructure and define their collaboration with elements of the world insurance market infrastructure.

Methodology. Such methods were used to do an abovementioned tasks: information collection about elements of European insurance market infrastructure; analysis of tendencies of the main indicators of the development of European insurance market from 2012 to 2016; generalization to characterize the elements of European insurance market infrastructure, define their collaboration with the elements of the world insurance market infrastructure and make conclusions.

Results. Main indicators of the development of European insurance market were increasing from 2012 to 2014 and decreasing from 2015 to 2016. Total premium volume as a share in GDP of Europe (insurance penetration) did not exceed $7 \%$ from 2012 to 2016 and as a share in the world GDP declined from $2.1 \%$ in 2014 to $1.95 \%$ in 2016. It was connected with results of the United Kingdom referendum on the European Union membership. The development of European insurance market is also under the influence of activity of elements of insurance market infrastructure such as Actuarial Association of Europe (AAE), Association of Mutual Insurers and Insurance Cooperatives in Europe (AMICE), European Financial Management Association (EFMA), European Insurance and Occupational Pensions Authority (EIOPA), European Federation of Insurance Intermediaries (BIPAR), European insurance and reinsurance federation (Insurance Europe), Geneva Association, Insurance Institute of London (IIL).

Value. This research indicates that the development of European insurance market infrastructure is caused by different factors: financial crises, legislation gap, improving the quality of information and others. Various of elements of European insurance market infrastructure were established to overcome such challenges and provide participants of insurance market with a necessary information, consultations, educational services and results of research, also through collaboration with elements of the world insurance market infrastructure. Results of this investigation can become a ground for further research in the field of defining an impact of activity of infrastructure elements on the development of an insurance market.
\end{abstract}

Keywords: insurance market, infrastructure, insurance intermediaries, insurance associations.

\section{Introduction}

European insurance market infrastructure includes various elements such as associations of insurers, insurance intermediaries, authorities and other organizations. They are established to achieve different goals. Appearing of new challenges in the insurance market leads to founding of appropriate insurance associations to overcome them. Therefore a study of the development of European insurance market infrastructure is quite important.

Lots of publications reflects general issues of the structure, regulation and growth of European insurance market. The structure of the financial system of the European Union including the structure of insurance market are considered in [1, 2]. Different aspects of regulation of European insurance market are presented in [3-5]. The key indicators of European insurance market are disclosed in $[6,7]$. However, far too little attention has been paid to European insurance market infrastructure.

\section{Analysis of literary data and statement of the problem}

Some authors investigate influence of financial crises [7, 9], political events such as Brexit $[4,8]$, regulatory acts such as Solvency II $[3,5]$ and entry of foreign insurance companies into national markets [2] on development of European insurance market and other markets. Another 
authors defined the connection between indicators of insurance market development and economic growth of European countries $[1,6,10]$. But there is a lack of attention to elements of infrastructure as a factor of progress of European insurance market.

\section{The aim and tasks of the research}

The aim of this paper is to consider the development of different elements of European insurance market infrastructure.

The next tasks of the study were done:

- to generalize main indicators of the development of European insurance market from 2012 to 2016;

- to characterize elements of European insurance market infrastructure and define their collaboration with elements of the world insurance market infrastructure.

\section{Materials and Methods}

The following methods were used to do an abovementioned tasks: information collection about elements of European insurance market infrastructure; analysis of tendencies of the main indicators of the development of European insurance market from 2012 to 2016; generalization to characterize the elements of European insurance market infrastructure, define their collaboration with the elements of the world insurance market infrastructure and make conclusions. Information and data for this research are from official web sites of the elements of European insurance market infrastructure and Swiss Re Institute's publications

\section{Results}

Main indicators of the development of European insurance market were increasing from 2012 to 2014 and decreasing from 2015 to 2016, what is presented in Table 1.

Table 1

Indicators of the development of European insurance market from 2012 to 2016

\begin{tabular}{|c|c|c|c|c|c|c|c|}
\hline \multirow{2}{*}{ Indicator } & \multirow{2}{*}{2012} & \multirow{2}{*}{2013} & \multirow{2}{*}{2014} & \multirow{2}{*}{2015} & \multirow{2}{*}{2016} & \multicolumn{2}{|c|}{ Tendencies } \\
\hline & & & & & & $2014 / 2012$ & $2016 / 2014$ \\
\hline $\begin{array}{l}\text { Life insurance premium } \\
\text { volume, bln of USD }\end{array}$ & 881.00 & 933.72 & 1002.56 & 872.00 & 858.6 & $\uparrow$ & $\downarrow$ \\
\hline $\begin{array}{l}\text { Non-life insurance premium } \\
\text { volume, bln of USD }\end{array}$ & 659.68 & 686.41 & 692.53 & 597.00 & 611.4 & $\uparrow$ & $\downarrow$ \\
\hline $\begin{array}{l}\text { Total premium volume, } \\
\text { bln of USD }\end{array}$ & 1540.68 & 1620.13 & 1695.09 & 1469.00 & 1470.0 & $\uparrow$ & $\downarrow$ \\
\hline $\begin{array}{l}\text { Insurance density: } \\
\text { premiums per capita in USD }\end{array}$ & 1724.4 & 1833.5 & 1902.0 & 1634.4 & 1620.0 & $\uparrow$ & $\downarrow$ \\
\hline Insurance penetration, $\%$ & 6.73 & 6.82 & 6.83 & 6.89 & 6.73 & $\uparrow$ & $\downarrow$ \\
\hline $\begin{array}{l}\text { Total premium volume as } \\
\text { a share in the world GDP, } \%\end{array}$ & 2.17 & 2.19 & 2.19 & 2.0 & 1.95 & $\uparrow$ & $\downarrow$ \\
\hline
\end{tabular}

Source: compiled by the author based on Swiss Re Institute's data [11-15]

Table 1 shows that total premium volume as a share in Gross Domestic Product (GDP) of Europe (insurance penetration) did not exceed $7 \%$ from 2012 to 2016 and as a share in the world GDP declined from $2.1 \%$ in 2014 to $1.95 \%$ in 2016. It was connected with results of the United Kingdom referendum on the European Union membership [14]. It is necessary to mention that the United Kingdom insurance market is the biggest in Western Europe.

The development of European insurance market is also under the influence of activity of elements of insurance market infrastructure such as Actuarial Association of Europe (AAE), Association of Mutual Insurers and Insurance Cooperatives in Europe (AMICE), European Financial Management Association (EFMA), European Insurance and Occupational Pensions Authority (EIOPA), 
European Federation of Insurance Intermediaries (BIPAR), European insurance and reinsurance federation (Insurance Europe), Geneva Association, Insurance Institute of London (IIL) (Table 2).

Table 2

Characteristic of elements of European insurance market infrastructure

\begin{tabular}{cl}
\hline Element & \multicolumn{1}{c}{ Characteristic } \\
\hline $\begin{array}{c}\text { Actuarial } \\
\begin{array}{c}\text { Association of Europe } \\
\text { (established in 1978) }\end{array}\end{array}$ & $\begin{array}{l}\text { Its purpose is to provide advice and opinions to the various organizations of the European Union - the } \\
\text { on actuarial issues in European legislation. The AAE currently has 36 member associations in 35 Eu- } \\
\text { ropean countries, representing over 22,000 actuaries. Advice and comments provided by the AAE on } \\
\text { behalf of the European actuarial profession are totally independent of industry interests }\end{array}$
\end{tabular}

Association of Mutual

Insurers and Insurance

Cooperatives in Europe

(established in 2008)

European Financial

Management Association

(established in 1971)

Provides a platform for mutual and cooperative insurers of all sizes to combine resources and expertise, exchange experiences across national borders and discuss key issues and concerns relating to planned legislative and regulatory changes and developments

Not-for-profit association formed by bankers and insurers, specializes in retail financial marketing and distribution. More than 3,300 brands in 130 countries are EFMA members including over $80 \%$ of Europe's largest retail financial institutions

European Insurance and Occupational Pensions Authority (established in 2001)

The core responsibilities are to support the stability of the financial system, transparency of markets and financial products as well as the protection of policyholders, pension scheme members and beneficiaries. EIOPA is commissioned to monitor and identify trends, potential risks and vulnerabilities stemming from the micro-prudential level, across borders and across sectors

European Federation of Insurance Intermediaries (established in 1937)

Primary mission is to promote a European regulatory environment in which intermediaries can prosper and that, at the same time, can ensure fair competition, an adequate level of consumer protection and a sound insurance and financial market. BIPAR is also a platform to develop coordinated actions in the interest of the European community of insurance and financial intermediaries

Mission is: To draw attention to issues of strategic interest to all European insurers and reinsurers in a sustainable manner

European insurance and reinsurance federation (founded in 1953)

To raise awareness of insurers' and reinsurers' roles in providing insurance protection and security to the community as well as in contributing to economic growth and development.

To promote - as the expert and representative voice of the insurance industry - a competitive and open market to the benefit of the European consumer as well as corporate clients

Geneva Association (established in 1973)

Activity is connected with high-quality research and analysis on strategic insurance issues such as: Financial Stability and Regulation, Extreme Events and Climate Risk, Global Ageing, Cyber and Innovation, The Protection Gap

Insurance Institute of Lon- To ensure: "The cultivation of knowledge and information in all matters relating to the various branchdon (established in 1907) es of insurance" through its lecture and visits programmes, its journal and its research

Source: compiled by the author based on information from: [16-23]

Various abovementioned elements of European insurance market infrastructure were established in XX-XXI centuries to develop and support different aspects of insurance market: legislation, protection interests, education, research. It is difficult without collaboration with elements of the world insurance market infrastructure (Table 3).

Table 3

Collaboration with elements of the world insurance market infrastructure

\begin{tabular}{cc}
\hline Element of European insurance market infrastructure & Element of the world insurance market infrastructure \\
\hline Actuarial Association of Europe & International Actuarial Association \\
Association of Mutual Insurers and & The International Cooperative and Mutual Insurance Federation \\
Insurance Cooperatives in Europe & (ICMIF) - is a global partner of AMICE \\
European Federation of Insurance Intermediaries is & World Federation of Insurance Intermediaries (WFII)
\end{tabular}

European Insurance and Occupational Pensions Authority is a member of IAIS

International Association of Insurance Supervisors (IAIS)

Source: compiled by the author based on information from: $[16,17,19,20]$ 
The information from Table 3 makes possible to generalize that most elements of European insurance market infrastructure collaborate with its members, different organizations at micro level and with elements of the world insurance market infrastructure at macro level to achieve set goals, plans and positive results.

\section{Discussion}

Results of this investigation can become a ground for further research in the field of defining an impact of activity of infrastructure elements on development of the insurance market.

\section{Conclusions}

This study gives a possibility to make the next conclusions:

- indicators of the development of European insurance market is caused by different factors: financial crises, legislation gap and others;

- various of elements of European insurance market infrastructure were established to overcome such challenges and provide participants of insurance market with a necessary information, consultations, educational services and results of research, also through collaboration with elements of the world insurance market infrastructure.

\section{Acknowledgments}

This research received no specific grant from any funding agency in the public, commercial, or not-for-profit sectors.

\section{References}

[1] Boldeanu, F. T., Tache, I. (2016). The Financial System of the EU and the Capital Markets Union. European Research Studies, 19 (1), 59-70.

[2] Dickinson, G. M. Insurance markets within Western Europe: an analysis of recent structural changes. Available at: http://www.aulibrary.au.edu/multim1/ABAC_Pub/The-Journal-of-Risk-ManagementAnd-Insurance/v1-n1-1.pdf

[3] Doff, R. (2016). The Final Solvency II Framework: Will It Be Effective? The Geneva Papers on Risk and Insurance - Issues and Practice, 41 (4), 587-607. doi: 10.1057/gpp.2016.4

[4] Lannoo, K. (2016). EU Financial Market Access After Brexit. Intereconomics, 51 (5), 255-260. doi: 10.1007/s10272-016-0614-y

[5] Pradier, P.-C., Chneiweiss, A. (2017). The Evolution of Insurance Regulation in the EU Since 2005. Financial Regulation in the EU, 199-251. doi: 10.1007/978-3-319-44287-7_9

[6] Pradhan, R. P., Dash, S., Maradana, R. P., Jayakumar, M., Gaurav, K. (2017). Insurance market density and economic growth in Eurozone countries: the granger causality approach. Financial Innovation, 3 (1). doi: 10.1186/s40854-017-0065-x

[7] Vencappa, D., Fenn, P., Diacon, S. (2013). Productivity Growth in the European Insurance Industry: Evidence from Life and Non-Life Companies. International Journal of the Economics of Business, 20 (2), 281-305. doi: 10.1080/13571516.2013.782979

[8] Sholoiko, A. (2014). Trends of development of the insurance market: national and world aspects. Bulletin of Taras Shevchenko National University of Kyiv Economics, 156, 60-65. doi: 10.17721/17282667.2014/156-3/12

[9] Rasshyvalov, D. (2017). Brexit fallout for british and world insurance market: operational and institutional aspects. Bulletin of Taras Shevchenko National University of Kyiv Economics, 194, 29-34. doi: $10.17721 / 1728-2667.2017 / 194-5 / 4$

[10] Zaletov, O. M. (2012). The role of the insurance market in the system of socio-economic relations: the experience of Europe. Insurance TOP, 3, 76-80.

[11] Swiss Re. World Insurance in 2012: Progressing on the long and winding road to recovery (2013). Sigma, No. 3, 46. Available at: http://media.swissre.com/documents/sigma3_2013_en.pdf

[12] Swiss Re. World Insurance in 2013: Steering towards recovery (2014). Sigma, No. 3, 47. Available at: http://media.swissre.com/documents/sigma3_2014_en.pdf 
[13] Swiss Re. World Insurance in 2014: Back to life (2015). Sigma, No. 4, 48. Available at: http:// media.swissre.com/documents/sigma4_2015_en.pdf

[14] Swiss Re. World Insurance in 2015: Steady growth amid regional disparities (2016). Sigma, No. 3, 52. Available at: http://media.swissre.com/documents/sigma_3_2016_en.pdf

[15] Swiss Re. World Insurance in 2016: the China growth engine steams ahead (2017). Sigma, No. 3, 60. Available at: http://media.swissre.com/documents/sigma3_2017_en.pdf

[16] About the AAE. Available at: https://actuary.eu/about-the-aae/about-the-aae/

[17] What is AMICE? - About AMICE - AMICE. Available at: http://www.amice-eu.org/what_is amice.aspx

[18] Joining Efma. Efma. Available at: https://efma.com/about/joining

[19] Missions and tasks EIOPA. Available at: https://eiopa.europa.eu/about-eiopa/missions-and-tasks

[20] Mission. BIPAR. Available at: http://bipar.eu/en/page/mission

[21] About us. Insurance Europe. Available at: https://www.insuranceeurope.eu/about-us

[22] About Us. The Geneva Association. Available at: https://www.genevaassociation.org/about-us

[23] Our Role. The Insurance Institute of London. Available at: http://www.iilondon.co.uk/home/ about-us/our-role/ 